\title{
The effects of magnesium pemoline upon repeated acquisition and extinction of a bar press response
} PERRIE M. ADAMS, F. T. CRAWFORD, and W. GRANT
LEE, Florida State University, Tallahassee, Fla. 32306

Six groups of six rats were run for 15-min daily sessions in an operant situation under either magnesium pemoline $(M P)$ or saline conditions. The design consisted of four days of acquisition followed by two days of extinction repeated four times. The results indicated that there was a slight tendency for MP to maintain more resistance to extinction as measured by response rate. The differential resistance is decreased by further acquisition-extinction sessions beyond the second set. The possible facilitating effects of MP are apparently reduced by the repeated exposure to the acquisitionextinction conditions.

Following the report of Glasky \& Simon (1966) on the brain RNA enhancement properties of magnesium pemoline (MP) a great deal of interest has been shown in its possible role for memory facilitation. Most experiments have employed the conditioned avoidance paradigm. Positive findings with avoidance studies (Plotnikoff, 1966; Beach \& Kimble, 1967; Powell, Martin, \& Kamano, 1967a, b; Filby, Szara, \& Salzman, 1967; Frey \& Polidora, 1967; Kulkarni, 1967; and Thompson \& Knudson, 1968) have indicated that MP may facilitate performance although the results have not always been interpreted as demonstrating an effect upon learning or memory. Negative findings with MP in an avoidance task have been reported by Cyert, Moyer, \& Chapman (1967), Chase \& Rescorla (1968), and Gurowitz et al (1967).

There have been relatively few studies involving the effects of MP in positively reinforcing situations. The effect of MP on performance in a Hebb-Williams maze was investigated by Lubar et al (1967). Their findings indicated that MP Ss had significantly better time and error measures but that the differences were due to the MP Ss' markedly superior performance on initial trials. Filby \& Frank (1968) investigated MP effects using a drl schedule of reinforcement and found that MP did not facilitate performance. The effect of MP on acquisition and extinction of a bar-press response was investigated by Grosser et al (1967). Their results indicated MP had no effect on acquisition but did significantly affect the magnitude of responding in extinction. The present study attempted to further evaluate the effect of MP upon the repeated acquisition and extinction of a bar-press response.

\section{SUBJECTS}

The Ss were 36 experimentally naive, male albino rats raised in the laboratory at Florida State University. They were 120-150 days of age at the start of the study and were maintained in individual cages on ad lib food.

\section{APPARATUS}

The apparatus consisted of two operant conditioning chambers. Programming and recording were done by solid-state electronic equipment, electric counters, and cumulative recorders.

\section{PROCEDURE}

Subjects were water-deprived for three days prior to the beginning of training. They were then shaped to bar press for water reinforcement on a continuous reinforcement schedule (CRF). Following each session Ss were given $40 \mathrm{~min}$ of ad lib water in their home cage. Ss were gradually brought up to a fixed ratio 10 (FR-10) schedule of reinforcement with FR levels at $-1,-3,-5$, and -10 . Each daily session was $20 \mathrm{~min}$ in duration.
Table 1

Magnesium Pemoline (MP) and Saline (Sa) Conditions for the Acquisition and Extinction Sets

\begin{tabular}{|c|c|c|c|c|}
\hline \multicolumn{5}{|c|}{ Acquisition--Extinction Sets } \\
\hline Group & 1 & 2 & 3 & 4 \\
\hline 1 & MP & MP & $\mathrm{Sa}$ & $\mathbf{S a}$ \\
\hline 2 & MP & $\mathrm{Sa}$ & MP & Sa \\
\hline 3 & MP & Sa & $\mathrm{Sa}$ & MP \\
\hline 4 & Sa & Sa & MP & MP \\
\hline 5 & Sa & MP & $\mathrm{Sa}$ & MP \\
\hline 6 & Sa & MP & MP & $\mathrm{Sa}$ \\
\hline
\end{tabular}

Subjects were randomly assigned to six different groups. Each group received four sets of acquisition and extinction training consisting of four days of acquisition and two days of extinction. There were, therefore, six days in each set and a total of 24 days training. Each group received MP or a controlled injection of saline (Sa) in a different sequence. The six sequences and the experimental design are given in Table 1. On any one set there were $18 \mathrm{MP}$ Ss and $18 \mathrm{Sa}$ Ss. All Ss received the same total of the MP and $S$ a conditions.

The MP was administered intraperitoneally (IP) at $20 \mathrm{mg} / \mathrm{kg}$ body weight. The MP was suspended in $0.3 \%$ gum tragacanth. The control injection was a $0.5 \mathrm{cc}$ IP injection of saline. All injections were given $30 \mathrm{~min}$ prior to the start of each S's daily session.

\section{RESULTS}

There was no indication of performance facilitation for the MP-injected Ss in the mean response/min rates of the acquisition phase of each set. There was, however, a small increment in the acquisition rates across the four sets for all of the groups.

There also was no evidence of retention enhancement by MP for the extinction data when the six groups were compared. A comparison of the extinction data for Groups 1 and 4 (Fig. 1) showed the largest effect produced by MP. $T$ tests between each of the pairs of points for each day ( $A$ and $B$ ) of the four sets resulted in a significant difference for only the first day (A) data of the second set $(t=3.34$, significant at .05 level with $10 \mathrm{df}$ ).

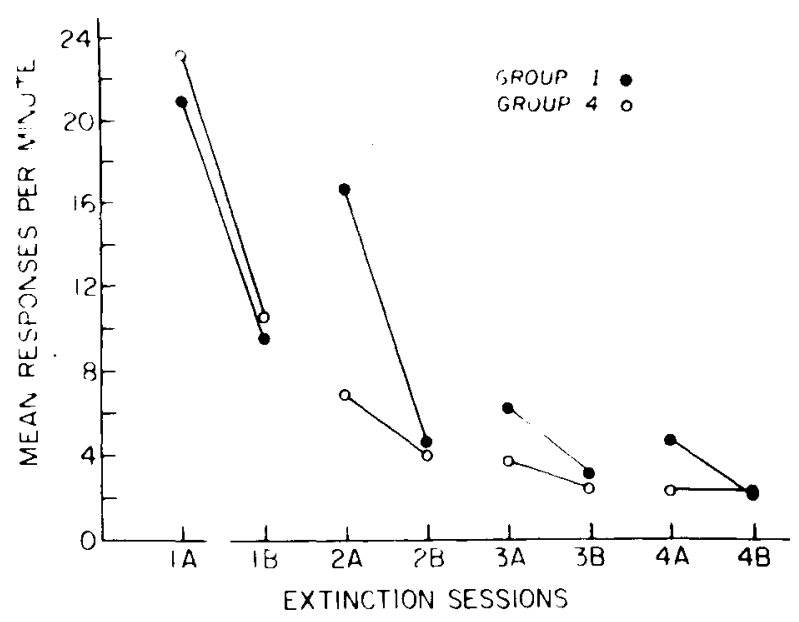

Fig. 1. Mean responses per minute for Groups 1 and 4 during the extinction periods of the four sets. 


\section{DISCUSSION}

The results indicated that there were no significant performance differences in the acquisition data regardless of the presentation sequence of MP and saline conditions. The small increment in the response rate over the four acquisition sets can probably be attributed to the repeated presentation of acquisition-extinction conditions.

The extinction data indicated that only for the Group 1 sequence vs the Group 4 sequence were significant differences in the response rates present. These differences were limited to a significantly higher response rate by Group 1 Ss on the first day of the second set's extinction phase.

The failure of MP to produce a significant facilitation in performance in the present study may be the result of the control the schedule of reinforcement holds over the performance. The data do not support the positive findings on acquisition enhancement noticed in the avoidance paradigms. Such differences may be the result of MP effects specific to certain response topologies.

It is concluded that possible performance or retention enhancement effects of MP are not clearly evident in the present study, nor in many others, and that further experimentation is necessary.

\section{REFERENCES}

BEACH, G., \& KIMBLE, D. P. Activity and responsivity in rats after magnesium pemoline injections. Science, $1967,155,698$.

CHASE, T. C., \& RESCORLA, R. A. The effect of magnesium pemoline on learning an active avoidance-passive avoidance discrimination. Psychonomic Science, 1968, 10, 87-88.

CYERT, L. A., MOYER, K. E., \& CHAPMAN, J. A. Effect of magnesium pemoline on learning and memory of a one-way avoidance response.
Psychonomic Science, 1967, 7, 9-10.

FILBY, Y., SZARA, S., \& SALZMAN, B. Magnesium pemoline: Effect on acquisition and retention of discriminated avoidance behavior. Psy chonomic Science, 1967, 9, 131-132.

FILBY, Y., \& FRANK, L. Magnesium pemoline: Effects on drl performance. Psychonomic Science, 1968, 10, 265-266.

FREY, P. W., \& POLIDORA, V. J. Magnesium pemoline: Effect on avoidance conditioning in rats. Science, 1967, 155, 1281.

GLASKY, A. J., \& SIMON, L. N. Magnesium pemoline: Enhancement of brain RNA polymerases. Science, 1966, 151, 702 .

GROSSER, G. S., SPRINTHALL, R. C., \& SIROIS, L. Magnesium pemoline: Activation of extinction responding after continuous reinforcement. Psychological Reports, 1967, 21, 11-14.

GUROWITZ, E. M., LUBAR, J. F., AIN, B. R., GROSS, D. A Disruption of passive avoidance learning by magnesium pemoline. Psychonomic Science, 1967, 8, 19-20.

KULKARNI, A. S. Magnesium pemoline: Facilitation of instrumental avoidance learning. Psy chonomic Science, 1967, 9, 39-40.

LUBAR, J. F., BOITANO, J. J., GUROWITZ, E. M., \& AIN, B. R. Enhancement of performance in the Hebb-Williams maze by magnesium pemoline. Psychonomic Science, 1967, 7, 381-382.

PLOTNIKOFF, N. Magnesium pemoline: Enhancement of memory after electroconvulsive shock in rats. Life Sciences, 1966, 5, 1495.

POWELL, B. J., MARTIN, L. K., \& KAMANO, D. K. Magnesium pemoline: Effects of training vs testing of an avoidance response. Psychonomic Science, 1967a, 8, 205-206.

POWELL, B. J., MARTIN, L. K., \& KAMANO, D. K. More on magnesium pemoline: Differential effects of advance and immediate injections on avoidance performance. Psychonomic Science, 1967b, 8 , 303-304.

THOMPSON, R. W., \& KNUDSON, G. R. Magnesium pemoline: Facilitation of one way and two way avoidance learning. Psychonomic Science, 1968, 11, 155-156.

\section{NOTE}

1. The authors thank Dr. Hollis G. Schoepke and Abbott Laboratories for supplying the magnesium pemoline used in this study. control group averaged $3.2 \mathrm{sec}$ and $11.9 \mathrm{sec}$ on avoidance and escape trials, respectively, while Group ASP averaged $4.5 \mathrm{sec}$ and $13.6 \mathrm{sec}$. Groups A and SP were not significantly different from control Ss on any measure.

Histology revealed extensive lesions in the target areas and supported the behavioral results, indicating that lesion location within the anterior cingulate area was not related to CAR in any obvious manner. Figure 3 shows sagittal view drawings of the lesioned areas. The largest and smallest lesions in the various groups are shown. The lesions were fairly symmetrical bilaterally, and extended approximately $1.0 \mathrm{~mm}$ laterally from the midline. The extent of damage to the combined areas was negatively correlated $(p=-0.47, p<.05)$ with CAR performance for all three experimental groups. Only one $\mathrm{S}$ showed a lesion as extensive as those of Trafton's (1967) anterior cingulate lesion groups and that $S$ avoided only once in 150 trials. The difference in the degree of damage probably accounts for the partial learning of Group ASP whereas Trafton's Ss showed no evidence of CAR learning in 100 trials.

The results seem to indicate that, at least for CAR learning in a shuttle box, the areas lesioned in the present study are a functional unit, as indicated by Kuhlenbeck et al (1960). The cytoarchitectonic parcellation of Krieg (1946) does not appear to be related to CAR performance as measured by the present study.

\section{REFERENCES}

KRIEG, W. J. S. Connections of the cerebral cortex. I. The albino rat. A. Topography of the cortical areas. B. Structure of the cortical areas. Journal of Comparative Neurology, 1946, 84, 221-225, 277-323.

KUHLENBECK, H., SZEKELY, E. G., \& SPULER, H. Some remarks on the zonal pattern of mammalian cortex cerebri as manifested in the rabbit: Its relationship with certain electrocorticographic findings. Confinia Neurologica, 1960, 20, 407-423.
(A)

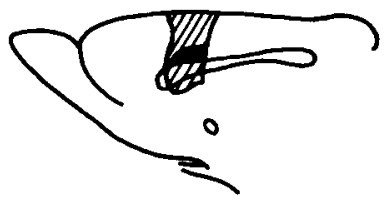

(SP)

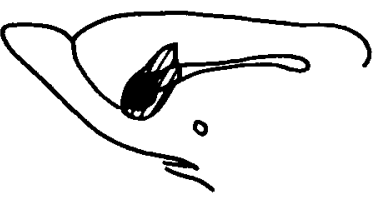

(ASP)

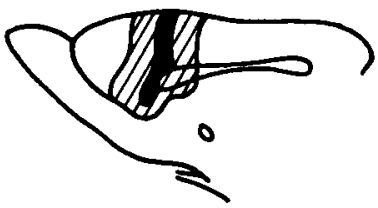

Fig. 3. Anterior midline cortex lesions for Groups A, SP, and ASP. The cross-hatched area represents the extent of the largest lesion, and the darkened area represents the extent of the smallest lesion in the group.

TRAFTON, C. L. Effects of lesions in the septal area and cingulate cortical areas on conditioned suppression of activity and avoidance behavior in rats. Journal of Comparative \& Physiological Psychology, 1967, 63, 191-197.

NOTE

1. This research was carried out at Pomona College, Claremont, California and was partially supported by a Ford Foundation grant. 